\title{
Top-down and bottom-up effects on zooplankton size distribution in a deep stratified lake
}

\author{
Lisa-Marie Braun · Sandra Brucet · Thomas Mehner
}

Received: 1 October 2020/Accepted: 15 February 2021 / Published online: 5 March 2021

(C) The Author(s) 2021

\begin{abstract}
Trophic interactions in the pelagic area of lakes and the opposing effects of fish feeding (topdown) and phytoplankton biomass (bottom-up) on zooplankton communities are central topics in limnology. We hypothesized that zooplankton size distributions should be a more sensitive approach to disentangle top-down and bottom-up effects than the commonly measured zooplankton biomass. We examined zooplankton size distributions from 148 samples collected during summer months in the upper and lower pelagic layers of a deep mesotrophic lake among 13 years of sampling. Top-down effects, namely fish
\end{abstract}

Handling Editor: Télesphore Sime-Ngando.

Supplementary information The online version contains supplementary material available at https://doi.org/10.1007/ s10452-021-09843-8.

L.-M. Braun · T. Mehner ( $\bowtie)$

Leibniz-Institute of Freshwater Ecology and Inland Fisheries, Müggelseedamm 310, 12587 Berlin, Germany

e-mail: mehner@igb-berlin.de

L.-M. Braun

e-mail: braun@igb-berlin.de

S. Brucet

Aquatic Ecology Group, University of Vic - Central

University of Catalonia, Vic, Catalonia, Spain

e-mail: sandra.brucet@uvic.cat

S. Brucet

ICREA, Catalan Institution for Research and Advanced

Studies, Barcelona, Spain size and biomass, and bottom-up effects, including water temperature and total phosphorus and chlorophyll a concentrations, were considered. To add robustness to our analyses, we expressed the zooplankton size distributions as size spectra based on log-binning, as continuous size spectra and by the size diversity, a measure that has been developed to mimic taxonomic diversity indices. Among numerous regressions tested, significant top-down or bottom-up effects could rarely been detected. Our results indicate that the overall zooplankton size distribution was not significantly affected by fish predation and lake productivity measured as total phosphorus or chlorophyll a concentration. However, we found negative correlations between fish biomass and the preferred zooplankton prey, including Bosmina longirostris, Daphnia cucullata and nauplii in the upper depth layer. However, due to their small body size, low biomass and therefore relative small contribution to the zooplankton size distribution, predation on preferred zooplankton species did not translate into a statistically significant modification of the entire size spectrum. Consequently, the size spectrum seems to be relatively robust against predation effects, but might reflect the lake-wide energy availability and transfer efficiency in the food web.

Keywords Zooplankton size spectra $\cdot$ Pelagic $\cdot$ Topdown $\cdot$ Bottom-up 


\section{Introduction}

Trophic interactions in the pelagic area of lakes are one of the cornerstones of classical and modern limnology. Many scientific studies centred around the opposing effects of fish feeding (top-down) and phytoplankton biomass (bottom-up) on zooplankton communities (Brooks and Dodson 1965; Carpenter et al. 1985; McQueen et al. 1986), while recent studies have also recognised the importance of the conditions at which top-down and bottom-up effects dominate (Carpenter et al. 2016). Zooplankton are an integral part of aquatic ecosystems, playing a crucial role in linking primary producers and higher trophic levels such as fish. In turn, zooplankton communities are sensitive to changes of their resources and their predators, and therefore mirror a balance of food web processes by their body size distribution and taxonomic composition (Mills and Schiavone 1982; Hansson et al. 2007).

However, detecting bottom-up and top-down effects on zooplankton becomes complicated because the zooplankton community is not a homogenous group, but is composed of several taxonomic and functional groups (e.g., cladocerans vs. copepods; filter-feeders vs. particulate feeders; herbivorous vs. omnivorous or carnivorous species). Accordingly, both the selective feeding of zooplankton on phytoplankton and the selective feeding of zooplanktivorous fish on zooplankton may modify the relative densities of zooplankton taxa and subsequently the strength of competitive interactions within the zooplankton community. It is therefore not surprising that studies on pelagic food chains have not identified a single 'master' mechanism, which drives the zooplankton community composition and biomass in the pelagic area of all lakes.

In contrast, it might be possible that the zooplankton size distribution is a more sensitive reflection of the strength of bottom-up or top-down effects in pelagic layers. The body size of individuals is a simple metric to collect, while it is a key characteristic correlated with physiological and ecological properties. The size of an organism scales with traits such as metabolic rate, growth (Marquet et al. 2005; Woodward et al. 2005), life span (Peters 1983; Calder 1984) and trophic position. In aquatic ecosystems, smaller organisms are typically more abundant than larger ones (Kerr 1974; Sprules et al. 1991; Thiebaux and
Dickie 1993). This negative relationship between size and abundance emerges from organism traits and ecological interactions (Sprules and Barth 2016) and is often referred to as a community size spectrum (SS). The SS describes the relationship between the logarithm of size and the logarithm of abundance, which is usually linear and can therefore be characterized by slopes and intercepts of linear regressions (Sheldon et al. 1972; Kerr and Dickie 2001). The intercept reflects the overall abundance of organism in the community and the slope mirrors the relative abundances of small and large organism (Ahrens and Peters 1991). Therefore, SS are a highly effective approach to summarize and compare the size structure of aquatic communities (Cottingham 1999; Cózar et al. 2003) and might be useful to evaluate resource availability for and selective predation on zooplankton communities.

A combination of abiotic and biotic factors influences zooplankton community size structure. Growth of zooplankton populations reflects factors regulating the metabolism, including temperature (Tordesillas et al. 2016) and food availability (Liu et al. 2015). Rising temperatures favour small organisms (Atkinson et al. 2003; Havens et al. 2015; Andersen et al. 2016) and therefore result in a shift towards smaller body size (Gardner et al. 2011), reflected in more negative SS slopes and lower size diversity, whereas greater resource availability leads to an increase in relative abundance of large organisms and therefore flatter SS slopes (Gaedke et al. 2004; Sprules and Barth 2016). Specifically, increases in total phosphorus (TP) lead to increases of overall zooplankton community abundances via higher food availability (Hanson and Peters 1984; Pinto-Coelho et al. 2005). However, top-down predation effects from fish (Jeppesen et al. 1997; Zhang et al. 2013) strongly affect biomass and body size distribution of zooplankton communities (Brooks and Dodson 1965; Badosa et al. 2007), leading to a reduced size diversity (Brucet et al. 2010). It is challenging to elucidate, which of these factors exhibit the greatest effect on trophic levels and therefore population dynamics and size structure, as the impact of each occurs simultaneously (Shurin et al. 2012; Liu et al. 2020) and interactive effects of these factors can be very complex.

In the present study, we used zooplankton SS to evaluate the strength of bottom-up and top-down directed effects on zooplankton size distributions in a 
deep mesotrophic lake. We examined the zooplankton size distribution from 148 samples collected exclusively during summer months among 13 years in the upper and lower pelagic layers of a deep mesotrophic lake. To add robustness to our analyses, we expressed the size distributions as SS based on log-binning, as continuous SS and by the size diversity, a measure that has been developed to mimic taxonomic diversity indices (Brucet et al. 2006, 2010, 2017; Quintana et al. 2008, 2016). We expected that both annually varying predation by the dominant pelagic planktivorous fish and resource availability via phytoplankton biomass would affect the year-to-year variation of the zooplankton size distributions. Therefore, we explored whether TP, chlorophyll a (chl a) concentrations and water temperature modified the size distribution of zooplankton. In turn, we tested whether the size distribution of fish and their biomasses as obtained by two different fishing methods had an effect on zooplankton size distributions. The lake is dominated by coregonid fishes, which show strong variations in year-class strength and annual growth rates resulting in strongly differing abundances between subsequent years (Helminen and Sarvala 1994; Auvinen et al. 2000; Viljanen et al. 2004; Mehner et al. 2011). Accordingly, strong inter-annual effects on their zooplankton prey can be expected. We hypothesized that the size distributions of zooplankton would show strong differences between years, which reflect the relative contributions of fish predation and resource availability. Therefore, we aimed to demonstrate that the size distribution of pelagic zooplankton communities is a superior and easy-to-generate metric that informs about the major structuring forces in the pelagic area of deep lakes.

\section{Materials and methods}

Study site and sampling

This study was conducted in Lake Stechlin, located approximately $120 \mathrm{~km}$ north of Berlin (Germany). This mesotrophic lake covers about $4.25 \mathrm{~km}^{2}$ with mean and maximum depths of $22.3 \mathrm{~m}$ and $69 \mathrm{~m}$, respectively (see Fig. 1a, Koschel and Adams 2003). A total of 13 fish species inhabit the lake, but the pelagic fish community is dominated by two sympatric species of ciscoes, Coregonus albula and C. fontanae (more than $95 \%$ of fish abundance; Mehner and Schulz 2002; Schulz and Freyhof 2003; Helland et al. 2007). Furthermore, the average stock exploitation rate by the single commercial fishery is 0.08 (Wanke et al. 2017), suggesting no strong effect of fish removal on fish abundance differences between years. We estimated counts and individual body wet mass (in g) of fish using a pelagic midwater trawl annually at the end of June between 2005 and 2018 ( $n=13$ years, data for 2016 missing due to net malfunction). Trawling is commonly employed for SS studies on fish, but its inherent size selectivity (Klein et al. 2019) may result in an overrepresentation of medium-sized fish. Therefore, simultaneously to trawling, we also performed hydroacoustic surveys to obtain pelagic fish mean mass (in g) and biomass (kilogram per hectare, see Fig. 1b).

\section{Crustacean assessment}

Crustacean plankton was collected by vertical tows in the upper depth layer from 0 to $22 \mathrm{~m}$ and the lower depth layer from 22.1 to $65 \mathrm{~m}$, using a cone-shaped closing net (mesh size $90 \mu \mathrm{m}$, opening $27 \mathrm{~cm}^{2}$; length $1.2 \mathrm{~m}$, Hydrobios, Kiel, Germany) at the deepest location of the lake (NE basin, $69.5 \mathrm{~m}$ ). Since fish data were exclusively collected in summer, we similarly considered only zooplankton samples collected during summer months between 2005 and 2018 (13 years, excl. 2016). Therefore, from June to August, the lake was sampled twice a month except 2014 (one sampling in August), 2015 (each month sampled only once) and 2018 (one sampling in August) resulting in a total of 148 zooplankton samples (74 samplings $\times 2$ depth layers). Samples were preserved in a $4 \%$ sugarformaldehyde solution. Taxa were identified according to Flößner (1972, 2000), Kiefer and Fryer (1978), Einsle (1993) and Lieder (1996). A sub-sample containing at least 100 individuals of the dominating species or groups was counted (abundance in Ind $\mathrm{m}^{-3}$ ) using an inverted microscope at 60-fold magnification. Mean length of zooplankton was estimated by measuring approximately 15 individuals per each frequent group (species level in most cases; see Table 1 in Appendix for list) and then transformed to carbon body mass $\left(\mu \mathrm{g} \mathrm{C} \mathrm{Ind}{ }^{-1}\right.$ ) using species-specific allometric equations from published studies (Bottrell et al. 1976; Kasprzak 1984). To examine the taxon-specific proportions from the entire zooplankton community in 
(a)

(b)

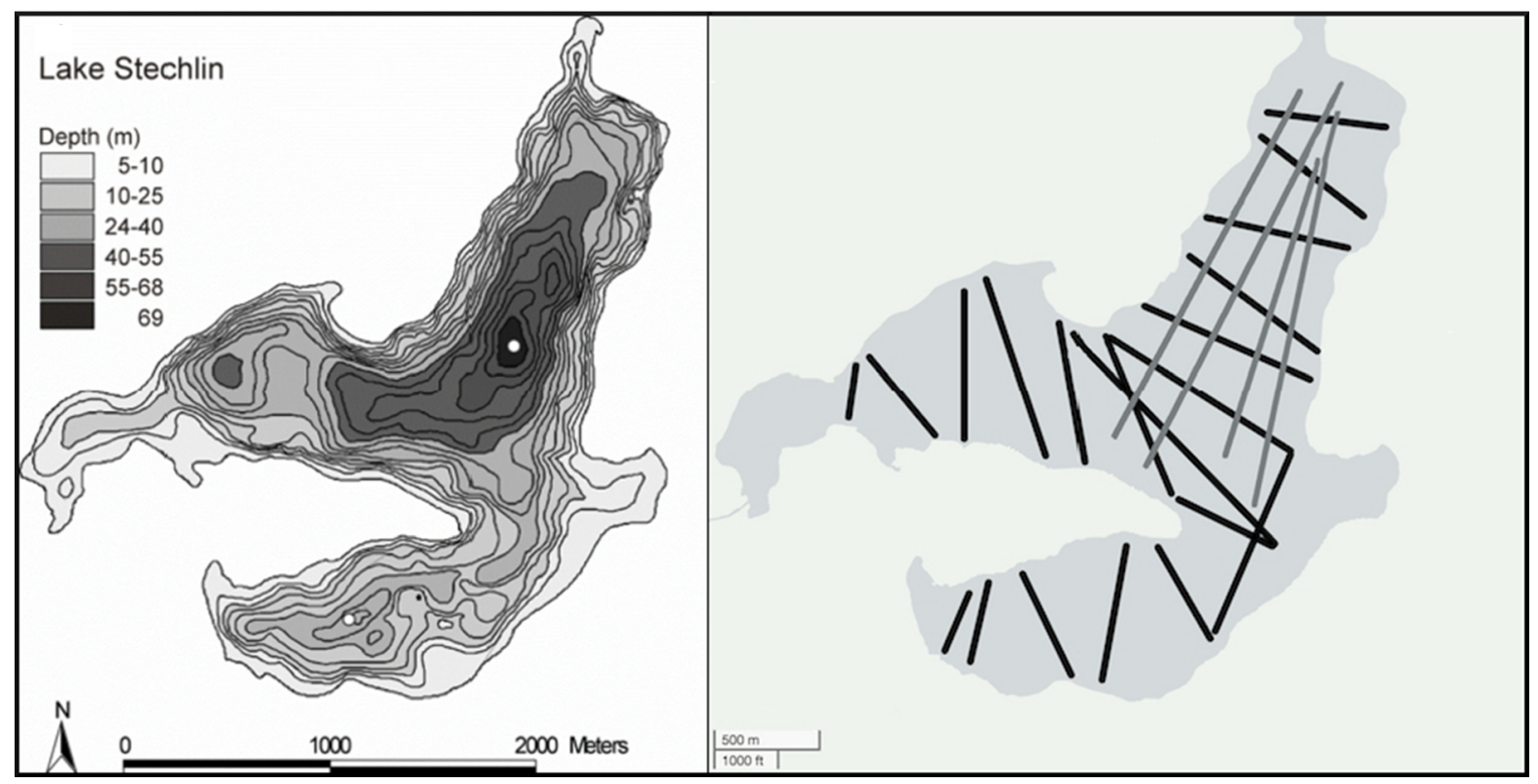

Fig. 1 Bathymetric map of Lake Stechlin indicating water depth (a) and map with transect lines from trawling (in grey) and hydroacoustic surveys (in black, b)

the upper and lower depth layers, we calculated the biomass of each taxon group for each depth layer. Abundance (Ind $\mathrm{m}^{-3}$ ) was multiplied with the carbon body mass for each taxon and the group-specific annual average biomass was determined from the individual samples.

\section{Fish assessment: trawling}

A pelagic trawl with $28 / 20 / 10 \mathrm{~mm}$ mesh size, $10 \mathrm{~mm}$ mesh size in the cod-end and a total length of $14.8 \mathrm{~m}$ (stretched on land) was utilized. The net with an opening area of approximately $10 \mathrm{~m}^{2}$ (opening width $3.5 \mathrm{~m}$ ) was towed by a boat (length $7 \mathrm{~m}$, width $2 \mathrm{~m}$ ), which was driven by a $60 \mathrm{hp}$ engine over four longitudinal transects in the deepest lake basins (see Fig. 1b). Trawling speed (mean \pm SD) was $6.5 \pm 0.6 \mathrm{~km} \mathrm{~h}^{-1}\left(1.8 \pm 0.2 \mathrm{~m} \mathrm{~s}^{-1}\right)$, while towed distance, as the product of trawling speed and trawling time, ranged between 500 and $1600 \mathrm{~m}$ (mean $840 \mathrm{~m}$ ) with an average towing time ( \pm SD) of $7.8 \mathrm{~min}$ $( \pm 1.9)$. During each survey, a total of four hauls were conducted at approximately $12 \mathrm{~m} \pm 0.65 \mathrm{~m}$, $15 \mathrm{~m} \pm 1.09 \mathrm{~m}, \quad 25 \mathrm{~m} \pm 2.08 \mathrm{~m} \quad$ and $32 \mathrm{~m} \pm 0.90 \mathrm{~m}$ (mean $\pm \mathrm{SD}$ ), whereby the two deeper hauls had shorter trawling times and slightly slower hauling speeds. Due to limited spatial extension of water layers with more than $35 \mathrm{~m}$ depth, deeper hauls could not be performed. The actual sampling depth was recorded with a diving computer attached on the trawl's head rope. The depth variability during each tow never exceeded $3 \mathrm{~m}$. At the end of each haul, the trawl was quickly lifted by hydraulic winches at speeds comparable to the trawling speeds, thus preventing escapement of fish from the net. Fish were counted, and individually measured to determine total length (TL, nearest centimetre) and body mass (wet mass, wm, nearest gram). Only subsamples were measured and weighed when catches were too large. The abundance of fish (Ind $1000 \mathrm{~m}^{-3}$ ) was estimated from the towed distance and the opening area of the trawl. Due to the shorter hauled distance in the deeper layers, the overall size distribution per year calculated as the total sum of all fish caught by the four hauls would have been biased towards the size of fish in the upper water layers. Therefore, we employed a weighting factor to calculate a weighted mean abundance and size distribution across the four depth layers. The weighting factor (WF) was calculated as the ratio between the maximum volume fished by one among the four hauls in this year and the volume fished in the respective depth. Accordingly, the WF equals the 
abundance and size distribution per depth layer to identical fished volumes. Some size distribution analyses require fish numbers per size class as integers; then the weighting factor was rounded to the nearest half integer (see Table 2 in Appendix for an example).

\section{Fish assessment: hydroacoustics}

Hydroacoustic surveys were completed as a series of transects using a SIMRAD (Kongsberg) EY60 splitbeam hydroacoustic unit $(120 \mathrm{kHz}$, circular transducers, beam width $7^{\circ} \times 7^{\circ}$, pulse duration $128 \mathrm{~ms}$, ping rate 3 pings $\mathrm{s}^{-1}$ ). After calibration with standard spheres provided by the manufacturer, the surveys were conducted during complete darkness starting $1 \mathrm{~h}$ after sunset every June between the 6th and 29th. Surveys were performed with vertical beaming along 20 transects (total distance about $12 \mathrm{~km}$ ) across this tri-basin lake, with transect length ranging from 635 to 1332 m (see Fig. 1b). Data were stored in a computer, processed and analysed by the postprocessing Sonar 5 Pro software (version 6.0.4-R340, Balk and Lindem 2017). The lower target strength (TS) threshold (as a measure of fish body length in $\mathrm{dB}$ ) was set to $-55 \mathrm{~dB}$ for the echogram corresponding to fish of an approximate total length of $4.2 \mathrm{~cm}$ and $0.42 \mathrm{~g} \mathrm{wm}$. Parameters for amplitude echograms were set $6 \mathrm{~dB}$ lower ($61 \mathrm{~dB}$ ) to accept targets out of the half power edge of the sound beam. The TS $(\mathrm{dB})$ of the targets was converted into fish total length $(\mathrm{cm})$ and body wm $(\mathrm{g})$ using the equation obtained for Coregonus spp. from Lake Stechlin by Mehner (2006a, b):

$\mathrm{TL}(\mathrm{cm})=10^{\left(\frac{(\mathrm{TS}+70.9)}{25.5}\right)}$

Wet mass $(\mathrm{g})=0.00507 \times(\mathrm{TL}(\mathrm{cm}) 3.088)$

The records from all 20 sampled transects were combined and averaged for each year. Fish biomass $\left(\mathrm{kg} \mathrm{ha}^{-1}\right.$ ) was obtained by echo-integration, by using the size-frequency distribution of the detected individual targets per transect.

\section{Environmental descriptor assessment}

Physical and chemical data were recorded at the deepest site of the lake, simultaneously with the crustacean data. Vertical profiles of water temperature $\left({ }^{\circ} \mathrm{C}\right)$ were determined every $5 \mathrm{~m}$ between the surface and $65 \mathrm{~m}$, while $\mathrm{TP}\left(\mathrm{mg} \mathrm{L}^{-1}\right)$ concentrations were measured from samples at $0,5,10,40,60$ and $65 \mathrm{~m}$ depth photometrically. TP was measured after wet digestion of unfiltered subsamples in an autoclave (potassium peroxodisulfate, $30 \mathrm{~min}, 134^{\circ} \mathrm{C}$ ). TP content was determined by flow analysis and spectrometric detection (Foss FIAstar 5000 Analyzer). Chl a $\left(\mathrm{mg} \mathrm{L}^{-1}\right)$ concentration was measured at 0,5 and $10 \mathrm{~m}$ depth using photometric determination (Hitachi spectrophotometer U-2900). The arithmetic means of temperature and TP per year were determined for the upper $(0-20 \mathrm{~m})$ and lower $(21-65 \mathrm{~m})$ layers separately, while the mean chl a concentration was only based on samples from the upper layer. However, since chl a concentration in shallower depths may have an effect on processes of the entire water column, the determined chl a mean was also utilized as a predictor for dependent variables in the lower layer.

\section{Data analyses}

Zooplankton abundances (Ind $\mathrm{m}^{-3}$ ) were classified into a total of 17 body mass size classes, ranging from 0.1 to $25 \mu \mathrm{g} \mathrm{C} \mathrm{Ind}^{-1}\left(\log _{2}\right.$ range: -3.36 to 4.63$)$ and logarithmically transformed (base 2) for each sampling in the upper and lower depth layer (total of 148). The arithmetic mean zooplankton abundances per size class based on all samplings in the upper or lower depth layers for each year were determined and log transformed. Therefore, zooplankton SS were calculated for each depth layer separately per year (total of $26 \mathrm{SS}, 2$ for each of the 13 years). We utilized the LT (log-transform) method where the $\log _{2}$ mean counts were aggregated in $\log _{2}$ size bins of constant width and plotted against the midpoint of the size interval. Ordinary least square regression (OLS) method was used to estimate the SS slope and intercept (Rice and Gislason 1996). The intercept of size spectra is a general measure of total organism abundance. Normality of data was visually examined and tested with a Shapiro-Wilk normality test.

For scrutiny, we also used the maximum likelihood estimation when fitting zooplankton size spectra (Edwards et al. 2017). Here individual zooplankton body masses were not binned, but utilized in continuous form. The exponent of the individual size distribution (b), known to be positively related to the slope of the SS, was determined for each summer 
Table 1 Individual response variables and independent variables included in the multiple regression analyses for the upper and lower depth layer (aindicates annual mean values based on all summer samplings)

\begin{tabular}{|c|c|c|c|}
\hline \multirow{2}{*}{$\frac{\text { Response variable }}{\text { Zooplankton }}$} & \multicolumn{3}{|c|}{ Independent variables } \\
\hline & & Fish & Environmental descriptors \\
\hline SS Slope (OLS) & Trawling & SS exponent b (MLE) & \\
\hline \multicolumn{4}{|l|}{ SS Intercept (OLS) } \\
\hline SS exponent $\mathrm{b}(\mathrm{MLE})^{\mathrm{a}}$ & & 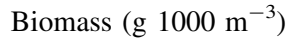 & \\
\hline Prey Taxa total abundance $\left(\text { Ind } \mathrm{m}^{3}\right)^{\mathrm{a}}$ & & & $\mathrm{Chl} \mathrm{a}+\mathrm{TP}+\mathrm{Temp}$ \\
\hline Prey Taxa Median Body Mass $(\mathrm{C} \text { ug })^{\mathrm{a}}$ & Hydro-acoustics & Mean mass $(\mathrm{g})$ & \\
\hline Size diversity ${ }^{\mathrm{a}}$ & & Biomass $\left(\mathrm{kg} \mathrm{ha}^{-1}\right)$ & \\
\hline
\end{tabular}

$S S$ size spectra, $O L S$ ordinary least square regression, $M L E$ maximum likelihood estimation, $C h l$ a chlorophyll a, $T P$ total phosphorus, Temp. temperature

sampling in the upper and lower layers. Then the arithmetic mean of exponent $b$ and the confidence interval were determined for each depth layer per year from these samplings. Furthermore, we determined zooplankton size diversity $(\mu)$ as based on carbon body mass $(\mu \mathrm{g} \mathrm{C})$, calculated from each sample and then averaged for each depth layer per year following Quintana et al. (2008), employing the Shannon diversity expression but adapted for body size as a continuous variable. Finally, we calculated the total biomass and median body mass of only those zooplankton taxa that are commonly included in Coregonus diet, which encompasses mainly cladocerans, including Daphnia spp., Bosmina spp., Chydorus sphaericus, Diaphanosoma brachyrum, Ceriodaphnia quandrangula and nauplii (Schulz et al. 2003) in each depth layer as a response variable. However, we did not calculate SS for the limited prey taxa as these only represent a fraction of the sizes of the entire community. Therefore, one cannot expect a negative relationship between size and abundance as predicted by SS theory for the entire zooplankton community.

Fish size distribution from trawling was comparably described as continuous SS using maximum likelihood estimation of $b$, which is the recommended method for fitting fish SS (Edwards et al. 2017). This was based on depth-weighted fish abundances. In addition, the arithmetic mean biomass $\left(\mathrm{g} 1000 \mathrm{~m}^{-3}\right.$, depth-weighted average from four trawl hauls) was calculated for each year. Finally, fish biomass as kilogram per hectare $\left(\mathrm{kg} \mathrm{ha}^{-1}\right)$ and mean mass (in $\mathrm{g}$ ) of fish were calculated from the hydroacoustic surveys.
To identify relationships between zooplankton community parameters (size distribution) and size or biomass of fish and mean TP, chl a and temperature, we utilized multiple regression analyses (see Table 1). Response variables tested in the multiple regressions were zooplankton slope and intercept (estimated by OLS) and zooplankton mean size diversity index, both per depth layer and year, annual summer averages of exponent $\mathrm{b}$ (estimated by MLE) of the SS, median body mass $(\mu \mathrm{g} \mathrm{C})$ and mean abundance (Ind $\mathrm{m}^{-3}$ ) of potential prey taxa in the upper and lower layer. As independent variables we utilized the exponent $b$ of the fish SS (estimated by MLE) and the mean fish biomass (g $1000 \mathrm{~m}^{-3}$, both from trawling), as well as mean mass $(\mathrm{g})$ and biomass $\left(\mathrm{kg} \mathrm{ha}^{-1}\right)$ as based on hydroacoustic surveys. Water temperature and mean chl a and TP concentrations were also included as environmental and productivity predictors, respectively, in all regressions. Only predictor variables that were not strongly cross-correlated (Pearson correlation coefficient below 0.5 , and Variance Inflation Factor (VIF) below 2) were included in the analyses (Belsley et al. 1980), as multicollinearity can result in inflated variance among predictors in the model. Automatic stepwise backwards selection and the Akaike information criterion (AIC) were used to select the variables in the final model by accounting for increasing complexity (as seen in Akaike 1974). The most parsimonious model obtained was the combination of variables that produced the lowest AIC. Residual partial plots for each significant variable were plotted to show the relationship between the predictor and the response variables. All statistical 
analyses and plots were conducted with the software R (version 4.0.0; R Development Core Team 2008). Specifically the MLE's of fish and zooplankton size spectra were performed by the provided $\mathrm{R}$ code and package (sizeSpectra) from Edwards et al. (2017) and Edwards (2020).

\section{Results}

Zooplankton community structure, abundance and biomass (2005-2018, excl. 2016)

During the summer months, the zooplankton community of Lake Stechlin was numerically dominated by copepod nauplii and Bosmina longirostris. Nauplii were most abundant (grand mean across all samples and years $=20,170$ Ind $\left.\mathrm{m}^{-3} \pm 8915\right)$ and Bosmina longirostris second most abundant $(\bar{x}=9540 \pm 9379$ Ind $\left.\mathrm{m}^{-3}\right)$ in the upper layer. In contrast, $B$. longirostris was most abundant $\left(\bar{x}=3624 \pm 3428\right.$ Ind $\left.\mathrm{m}^{-3}\right)$ and nauplii was the second most abundant group in the lower depth layer $\left(\bar{x}=1420 \pm 1180\right.$ Ind $\mathrm{m}^{-3}$; see Fig. 2, and Table 3 in Appendix). However, total zooplankton community biomass in the upper layer was clearly dominated by the calanoid copepod Eudiaptomus gracilis (10-30\%), with Daphnia cucullata (8-24\%) and nauplii (12-25\%) on the second and third rank. In the lower layer, Eurytemora lacustris (27-76\%) and Bosmina longirostris (4-47\%) contributed most to the overall zooplankton community (see Table 2). The body masses of zooplankton ranged from Chydorus sphaericus $\left(0.09 \mu \mathrm{g} \mathrm{C} \mathrm{Ind}^{-1}\right)$ in the upper layer to Cyclops spp. $\left(24.80 \mu \mathrm{g} \mathrm{C} \mathrm{Ind}^{-1}\right)$ in the lower depth layer. The mean $( \pm \mathrm{SD})$ body length and mass of the entire zooplankton communities were higher in the lower $(\bar{x} \quad 0.54 \pm 0.01 \mathrm{~mm}$; $\bar{x}=1.42 \pm 0.08 \mu \mathrm{g} \mathrm{C} \mathrm{bm)} \mathrm{than} \mathrm{in} \mathrm{the} \mathrm{upper} \mathrm{depth}$

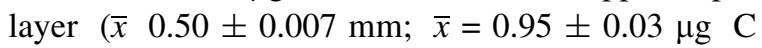
bm).

\section{Zooplankton spectral slope and shape and MLE b}

The zooplankton size distributions substantially deviated from a linear negative $\log -\log$ relationship, with only six out of the 26 ( 2 layers $\times 13$ years) linear regressions being significant $(p<0.05$, see Table 4 in Appendix). In most of the years, log size and log mean abundance exhibited a bimodal pattern (see
Figures 1-4 in Appendix). The highest mean abundance per body mass size-class was often observed in the $\log _{2}$ body mass classes -1.75 and -1.25 (0.20-0.41 $\mu \mathrm{g} \mathrm{C})$ dominated by Bosmina longirostris and nauplii and $\log _{2}$ body mass class 1.25 and 1.75 (1.68-3.35 $\mu \mathrm{g} \mathrm{C}$ ) dominated by Eudiaptomus gracilis, Daphnia cucullata and Eurytemora lacustris (see Table 3 in Appendix). Zooplankton spectral intercepts differed significantly between both depth layers. The mean intercept in the upper layer was significantly higher compared to the lower layer ( $t$ test: $\left.t_{(24)}=-15.09, p<0.0001\right)$. In contrast, mean spectral slopes were identical between upper and lower layers (t-test: $\left.t_{(26)}=-0.0005, p=0.99\right)$. The mean exponent $\mathrm{b}$ of the SS estimated by MLE was slightly higher in the upper than in the lower depth layer ( $t$ test: $\left.t_{(155)}=0.68, p=0.5\right)$. Zooplankton mean size diversity was significantly higher in the lower than in the upper layer $\left(t\right.$ test: $t_{(120)}=3.52, p<0.0006$, see Table 3).

Fish abundance and range between 2005 and 2018

Fish size distributions varied strongly between years, while the individual wet mass of fish sampled during trawling ranged from 0.018 to $103 \mathrm{~g}$. Some years were characterised by numerous small young fish (less than $4 \mathrm{~g}$ wet mass, e.g. in 2011 and 2017). In other years, bigger fish (17-32 g wet mass) dominated the community (e.g. in 2005 and 2008; see Fig. 3). The SS exponent $\mathrm{b}$ ranged from -1.6 to 0.42 . The steepest slopes and therefore the lowest spectral exponents were found in 2012 and 2017, which were characterised by a relatively high number of small fish in contrast to 2010 and 2014 which were characterised by numerous bigger and older fish (see Figures 5-8 in Appendix). Fish biomass $\left(\mathrm{g} 1000 \mathrm{~m}^{-3}\right)$ based on trawling varied $\approx$ fivefold (range $=140-749 \mathrm{~g}$ $\left.1000 \mathrm{~m}^{-3}\right)$, and mean biomass $\left(\mathrm{kg} \mathrm{ha}^{-1}\right)$ based on hydroacoustics differed $\approx$ threefold (range $=93-314 \mathrm{~kg} \mathrm{ha}^{-1}$ ) across years.

Effect of fish abundance and environmental descriptors on zooplankton community

Among the 48 combinations for 6 response variables and the 4 different fish predictors plus the 3 environmental predictors used in all analyses in two depth layers, the majority (45 out of 48) of the regressions 

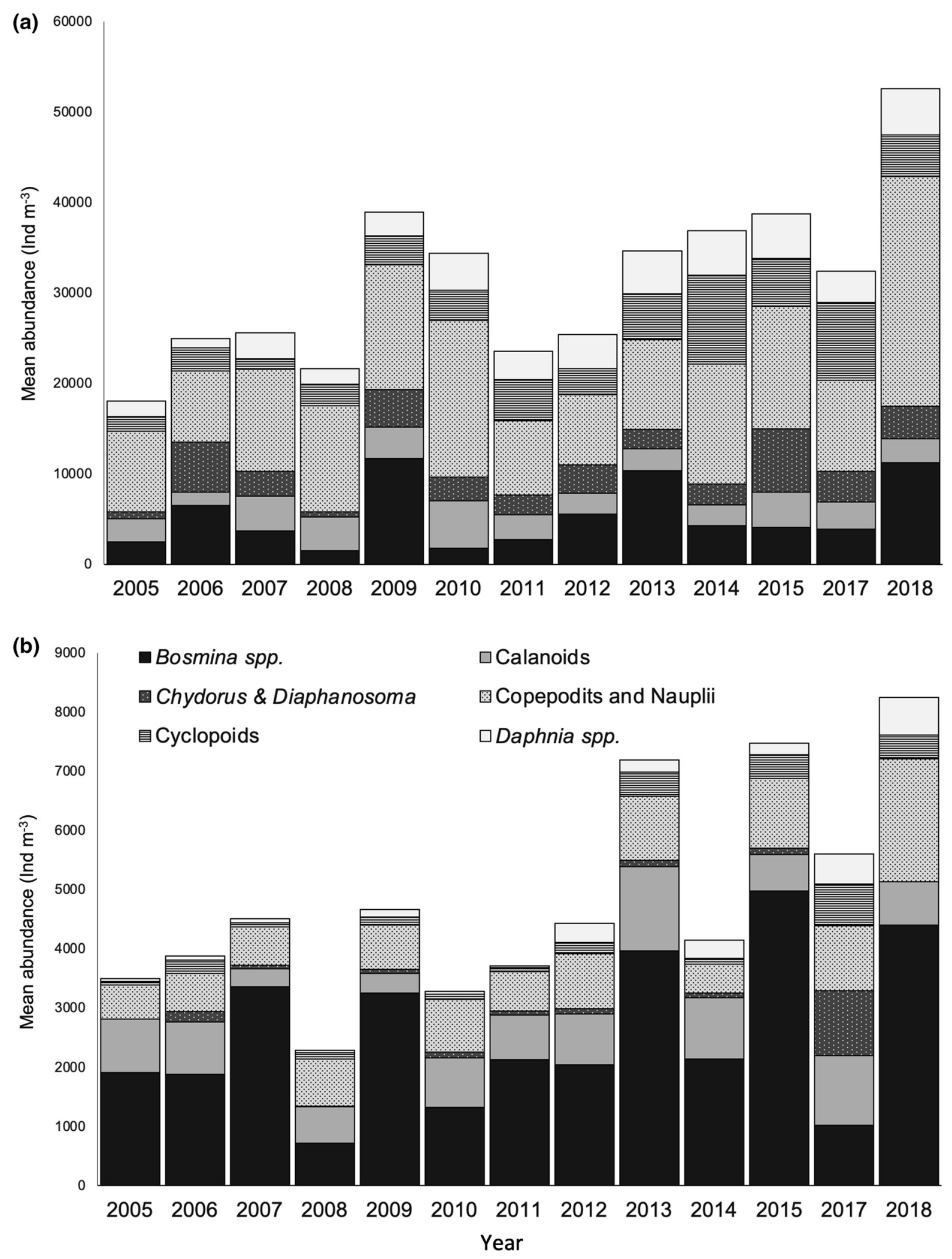
4Fig. 2 Mean abundance (Ind $\mathrm{m}^{-3}$ ) of zooplankton taxa grouped as: (1) Bosmina spp., (2) Chydorus spp. and Diaphanosoma spp., (3) calanoids, (4) copepodits and nauplii, and (5) Daphnia spp. for 2005-2018 (excl. 2016) in the a upper and b lower depth layer of Lake Stechlin

were not significant (see Table 5 in Appendix). Only the mean zooplankton spectral intercept (estimated by OLS) was significantly positively related to the exponent $\mathrm{b}$ of the fish SS from trawling, and was positively related to TP and negatively related to chl a in the upper depth layer $\left(R^{2}=0.64: F=5.5, d f=9\right.$, $p=0.01$; see Fig. 4). No similar correlations were found for the lower layer. Fish biomass $\left(\mathrm{kg} \mathrm{ha}^{-1}\right)$ based on hydroacoustics had a significantly negative effect on median body mass of potential fish prey taxa in the upper $\left(R^{2}=0.3, F_{(11)}=4.8, p=0.049\right)$ and lower depth layers $\left(R^{2}=0.53, \quad F_{(11)}=12.69\right.$, $p=0.004$, see Fig. 5).

\section{Discussion}

In our study, we aimed to determine top-down and bottom-up drivers for zooplankton size distribution in the pelagic area of the mesotrophic Lake Stechlin during summer months across 13 years of sampling. We tested seven commonly used parameters to describe the zooplankton community size structure and density from several successive years, by expecting that potentially strong effects from fish size or biomass and the environmental predictors would become visible on all or many of the six zooplankton parameters. Surprisingly, however, we found almost no effect of annual differences in fish size, biomass, $\mathrm{TP}$, chl a and temperature on the zooplankton size structure. This result seems to be robust because we expressed the zooplankton size structure as linearly binned SS, as continuous SS and as size diversity. Furthermore, the fish size and biomass data were obtained by two independent approaches, midwater trawling and hydroacoustics. We conclude that feeding by the zooplanktivorous coregonids in Lake Stechlin does not affect the size distribution of the entire pelagic zooplankton community. However, the few significant regressions indicate that there is a limited top-down effect on the density and size of those zooplankton taxa that constitute the major prey of the coregonids.

Our analyses have shown that fish size distributions as based on the exponent $b$ of the continuous SS
Table 2 Biomass proportion (\%, grand mean average from all samples between 2005 and 2018 (excl. 2016)) of each taxon group and their totals for taxa included (potential prey) and not included (no prey) in the diet of coregonids in the upper and lower depth layers of Lake Stechlin

\begin{tabular}{|c|c|c|}
\hline & Proportion (\%) & Total \\
\hline \multicolumn{3}{|l|}{ Upper depth layer } \\
\hline \multicolumn{3}{|l|}{ No prey } \\
\hline Eudiaptomus gracilis & 18.71 & 47.80 \\
\hline Eurytemora lacustris & 13.19 & \\
\hline Thermocyclops oithonoides & 7.04 & \\
\hline Cyclopoid Copepodit stages & 3.66 & \\
\hline Cyclops spp. & 2.21 & \\
\hline Copepodit stages & 2.04 & \\
\hline Mesocyclops leuckarti & 0.96 & \\
\hline \multicolumn{3}{|l|}{ Potential prey } \\
\hline Daphnia cucullata & 17.47 & 52.20 \\
\hline Nauplii & 15.40 & \\
\hline Bosmina longirostris & 6.98 & \\
\hline Diaphanosoma brachyurum & 5.46 & \\
\hline Daphnia hybrid & 2.32 & \\
\hline Ceriodaphnia quadrangula & 1.91 & \\
\hline Bosmina coregoni & 1.68 & \\
\hline Chydorus sphaericus & 0.98 & \\
\hline \multicolumn{3}{|l|}{ Lower depth layer } \\
\hline \multicolumn{3}{|l|}{ No prey } \\
\hline Eurytemora lacustris & 44.35 & 71.66 \\
\hline Cyclops spp. & 11.69 & \\
\hline Eudiaptomus gracilis & 7.26 & \\
\hline Cyclopoid Copepodit stages & 4.53 & \\
\hline Thermocyclops oithonoides & 1.68 & \\
\hline Copepodit stages & 1.14 & \\
\hline Mesocyclops leuckarti & 0.99 & \\
\hline \multicolumn{3}{|l|}{ Potential prey } \\
\hline Bosmina longirostris & 15.51 & 28.34 \\
\hline Nauplii & 5.44 & \\
\hline Daphnia cucullata & 3.57 & \\
\hline Diaphanosoma brachyurum & 1.22 & \\
\hline Daphnia hybrid & 0.97 & \\
\hline Chydorus sphaericus & 0.63 & \\
\hline Bosmina coregoni & 0.57 & \\
\hline Ceriodaphnia quadrangula & 0.44 & \\
\hline
\end{tabular}

obtained from trawling were significantly positively correlated with the spectral intercept of the zooplankton community in the upper layer of the lake. High $b$ 
Table 3 Zooplankton size metrices (response variables) mean, minimum, maximum and standard deviation (SD) for the upper (U) and lower (L) depth layers, as well as results from $t$ tests of

\begin{tabular}{|c|c|c|c|c|c|c|c|c|}
\hline \multirow[t]{2}{*}{ Response variable } & \multirow[t]{2}{*}{ Depth layer } & \multirow[t]{2}{*}{ Mean } & \multirow[t]{2}{*}{ Minimum } & \multirow[t]{2}{*}{ Maximum } & \multirow[t]{2}{*}{ SD } & \multicolumn{3}{|c|}{ Statistical analyses results } \\
\hline & & & & & & $t$ & $d f$ & $p$ value \\
\hline \multirow[t]{2}{*}{ Slope (OLS) } & $\mathrm{U}$ & -0.57 & -1.2 & 0.01 & 0.1 & \multirow[t]{2}{*}{-0.0005} & \multirow[t]{2}{*}{26} & \multirow[t]{2}{*}{0.9} \\
\hline & $\mathrm{L}$ & -0.57 & -1.1 & -0.02 & 0.1 & & & \\
\hline \multirow[t]{2}{*}{ Intercept (OLS) } & $\mathrm{U}$ & 13.7 & 12.4 & 14.5 & 0.2 & \multirow[t]{2}{*}{-15.1} & \multirow[t]{2}{*}{24} & \multirow[t]{2}{*}{$<0.0001$} \\
\hline & $\mathrm{L}$ & 10.4 & 9.7 & 11.3 & 0.1 & & & \\
\hline \multirow[t]{2}{*}{ b (MLE) } & $\mathrm{U}$ & -2.43 & -7 & -0.9 & 0.1 & \multirow[t]{2}{*}{0.68} & \multirow[t]{2}{*}{155} & \multirow[t]{2}{*}{0.5} \\
\hline & $\mathrm{L}$ & -2.3 & -7.4 & -0.7 & 0.1 & & & \\
\hline \multirow[t]{2}{*}{ Size diversity } & $\mathrm{U}$ & 1.2 & 0.04 & 1.7 & 0.04 & \multirow[t]{2}{*}{3.52} & \multirow[t]{2}{*}{120} & \multirow[t]{2}{*}{0.0006} \\
\hline & $\mathrm{L}$ & 1.5 & -0.04 & 2.3 & 0.06 & & & \\
\hline
\end{tabular}

OLS means size spectrum estimated by ordinary least squares, while MLE indicates fit of continuous size spectrum by maximum likelihood

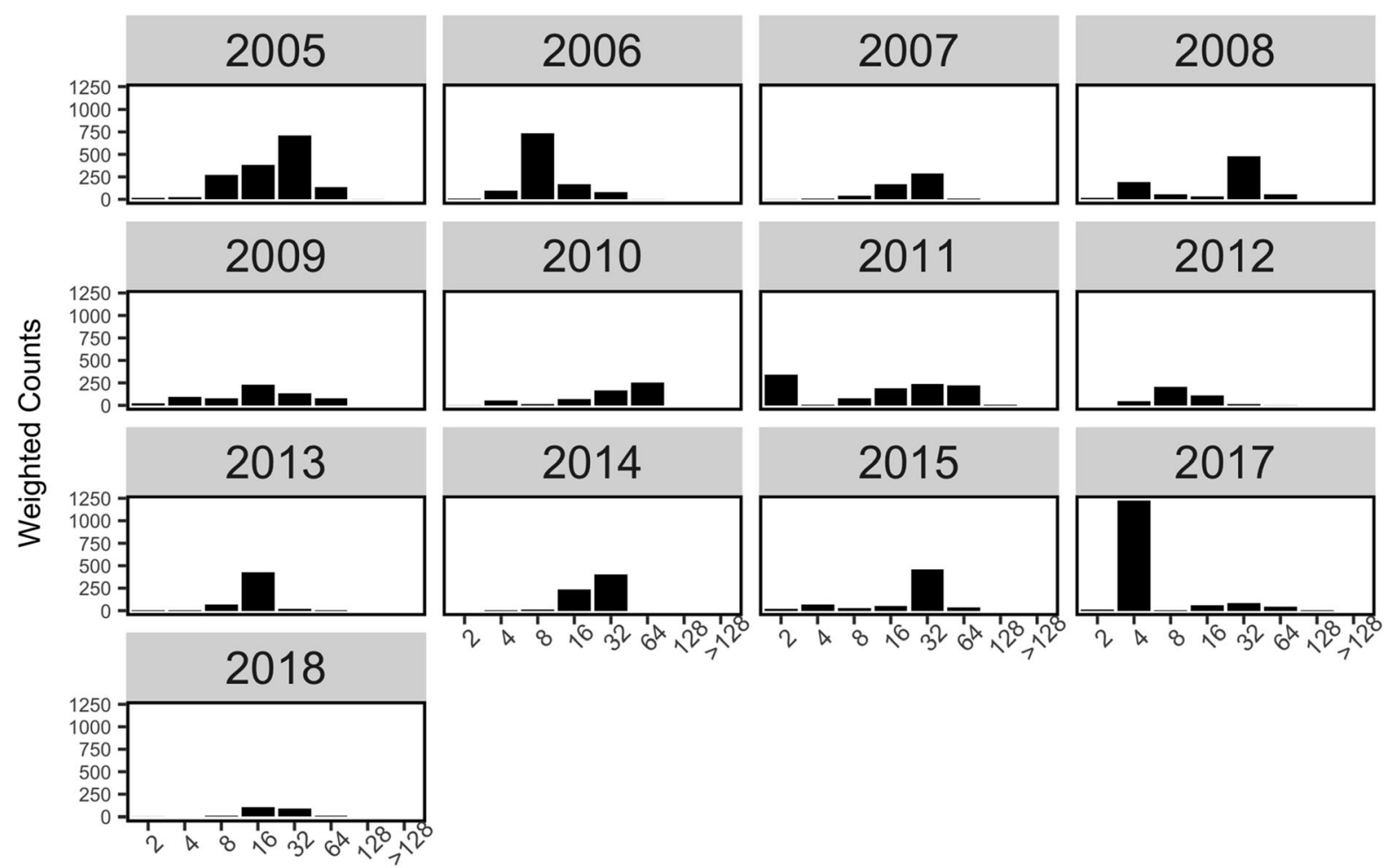

Body Wet Mass (g)

Fig. 3 Depth-weighted counts of fish distributed into body wet mass (g) classes as obtained from four trawling hauls in Lake Stechlin for each sampling year

exponents indicate a dominance of larger fish in the size distribution. Therefore, years with a relatively high number of medium and large-sized fish (e.g., in
2014 and 2015) were associated with a high density of zooplankton organisms (reflected by the intercept of the zooplankton SS). In contrast, years characterised 
Fig. 4 Partial residuals of the dependent variable zooplankton SS intercept from the significantly related independent variables fish size distribution exponent $\mathrm{b}(\mathbf{a})$, mean TP (b) and chl a (c) concentration (both $\mathrm{mg}$ $\mathrm{L}^{-1}$ ) in the upper depth layer of Lake Stechlin
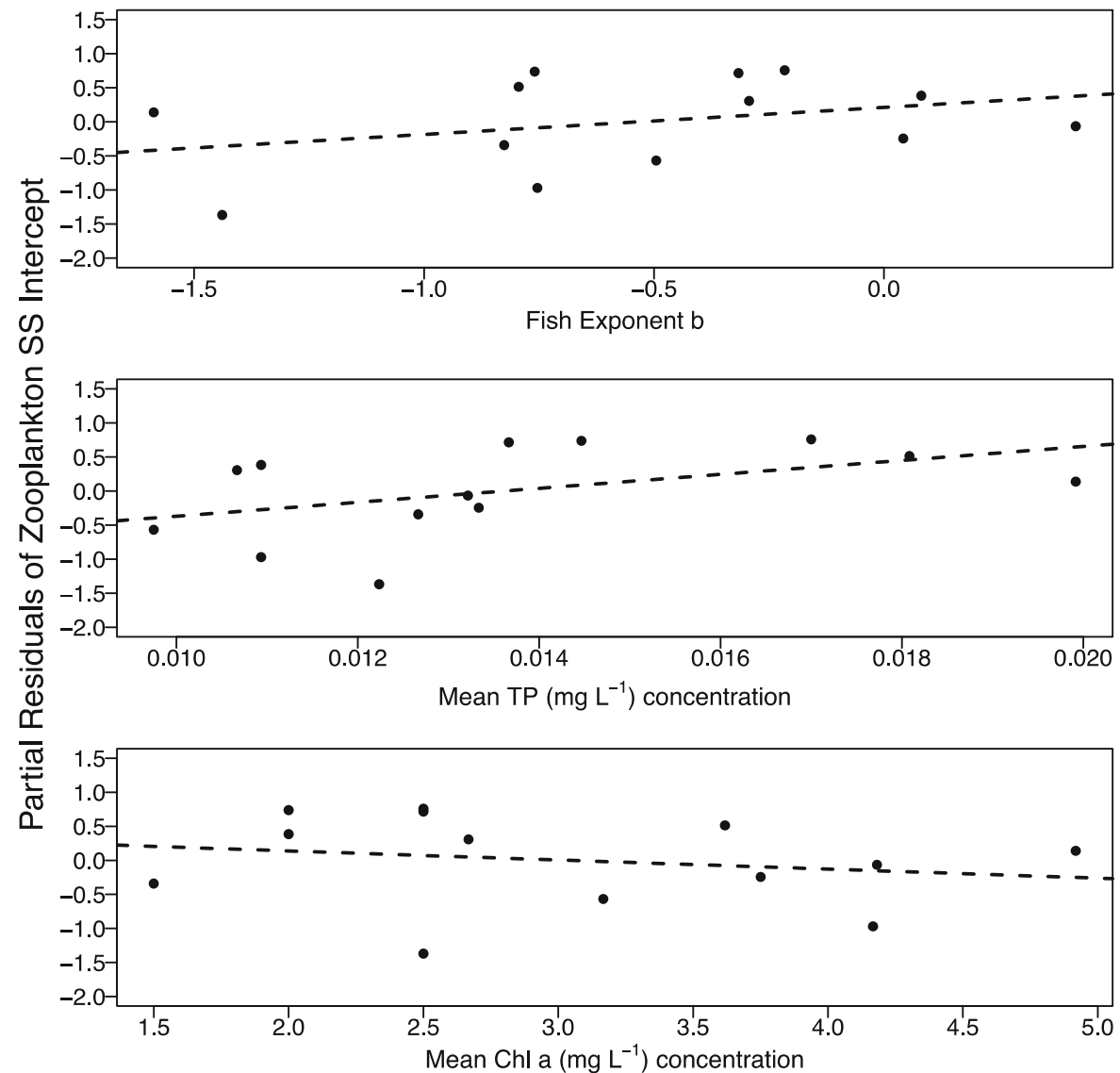

by numerous small fish (low exponent b, e.g. in 2012 and 2017) were associated with lower zooplankton densities. This positive relationship between zooplankton density and the contribution of larger coregonids to the size distribution may indicate that zooplankton density might be top-down controlled by fish feeding only in years with a dominance of small coregonids. Furthermore, a direct feeding effect of fish was reflected by the negative correlations between hydroacoustically estimated fish biomass and the median body mass of zooplankton prey taxa. These negative correlations were found in both the upper and lower layers. These results suggest that fish feeding might affect size structure and density of the zooplankton community, but with a stronger effect in the upper layers, and with a stronger effect on those cladocerans that constitute the prey of the coregonids (Schulz et al. 2003).

Cladocerans were more frequently found in the upper than in the lower water layer. Coregonids feed mainly during the day in the deeper hypolimnetic layers where light intensity is sufficient to allow for selective feeding (Gjelland et al. 2009; Mehner et al. 2010) and while migrating between the lower and upper hypolimnion close to the thermocline at low light conditions during dusk and dawn (Scheuerell and Schindler 2003; Gjelland et al. 2009). Therefore, coregonids in Lake Stechlin perform diel vertical migration for efficient zooplankton feeding, as the great majority of the cladoceran zooplankton in Lake Stechlin concentrate between the surface and $25 \mathrm{~m}$ depth (Kasprzak and Schwabe 1987). Our data were collected during summer months when the higher water temperatures that fish experience close to the thermocline, may result in higher daily basal energy requirements. It was already suggested by Mehner (2006a) that hungry juvenile coregonids prolong their stay in the shallower water layers, despite higher predation risk, to cope with the increasing energy demands during summer. Therefore, they may control the zooplankton density and size in the upper layers during years with a dominance of juvenile coregonids. 
Fig. 5 Partial residuals of the dependent variable median body mass of zooplankton taxa constituting coregonid prey and the independent variables fish biomass $(\mathrm{kg}$ $\mathrm{ha}^{-1}$ ) from hydroacoustic surveys in the upper (a) and lower (b) depth layers of Lake Stechlin

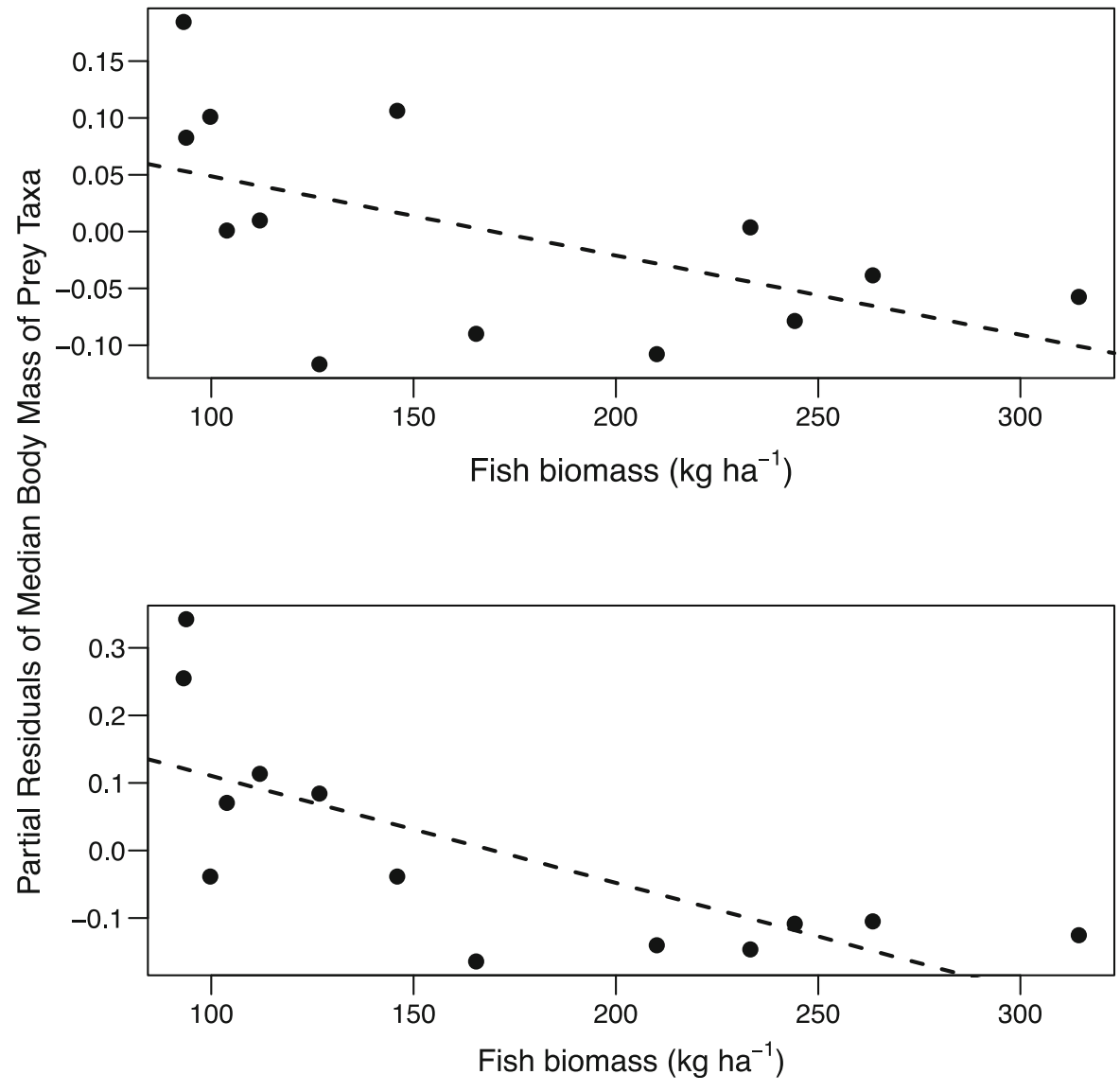

Previous studies in Lake Stechlin suggested that the top-down control of the zooplankton biomass by fish predation was unlikely, as trophic transfer efficiency between zooplankton and fish was determined to be relatively low (6\%, Schulz et al. 2004). Although prey taxa dominated the upper layer in numbers, we found that prey and non-prey taxa contributed equal amounts of biomass to the zooplankton community in the upper layer. Furthermore, it was shown in a previous study that specifically in summer months pelagic coregonids feed preferentially upon Bosmina longirostris and $B$. coregoni (Schulz et al. 2003), whilst these taxa contribute only $9 \%$ to the total zooplankton community biomass in the upper layer. Therefore, even if they are eaten by fish, their removal has only a minimal impact on the size distribution of the entire zooplankton community. Even more drastically it can be seen in the lower layer, where prey taxa of coregonids likewise dominate in numbers but they contribute only by $28 \%$ to the biomass of the zooplankton community. In contrast, the much bigger Eurytemora lacustris, which is not fed upon by the fish, contributes $44 \%$ to the community biomass alone. The data obtained here support that the size distribution of the entire zooplankton community is not top-down controlled by fish feeding. There are signs of negative correlations between zooplankton prey size and biomass of smaller coregonids, but these effects are obviously not strong enough to induce traceable changes in the size structure of the entire zooplankton community. These results support that pelagic trophic cascades are weak in lakes with lower productivity (Elser and Goldman 1991; Persson and Diehl 1992; Sarnelle 1992; Mehner et al. 2008).

As the productivity of Lake Stechlin has increased during the last decade (see Figures 9, 10 in Appendix), we expected that chl a and TP concentrations would likewise affect zooplankton size distributions across the years. However, we found only a weak positive effect by TP on zooplankton density (reflected by the intercept of the size spectra), whereas chl a was negatively correlated with the spectral intercept in the 
upper layer. This result is in part counterintuitive because we would have expected a positive correlation between zooplankton resources (phytoplankton biomass expressed as chl a) and zooplankton density. However, a recent long-term study from Lake Stechlin found evidence for a decreasing efficiency in trophic coupling between zooplankton and phytoplankton caused by an increasing dominance of filamentous cyanobacteria in the phytoplankton community (Selmeczy et al. 2019). Cyanobacteria are a known inadequate food source for zooplankton (Gulati and DeMott 1997) and therefore their dominance reduced the resource use efficiency and biomass of zooplankton. This dynamics may explain the significant negative relationship of chl a and zooplankton spectral intercept found in the upper layer in our study. However, these correlations became only visible in the multiple regression when the exponent of the fish SS was likewise included. Therefore, another plausible explanation would be that in years with a dominance of small coregonids, the zooplankton density (primarily cladocerans) is diminished, and the lower cladoceran density cascades down to a higher phytoplankton biomass in the upper layer of Lake Stechlin. Overall, however, there is a long-term signal that the increasing TP concentrations may increase the zooplankton densities via bottom-up control. In a recent comparative study across more than 200 lakes it has been clearly shown that chl a concentrations are more strongly bottom-up correlated with fish production rates, than fish feeding rates affect chl a concentrations negatively in the sense of top-down control (Bartrons et al. 2020).

There are several insights from the results that might be important for food web studies beyond Lake Stechlin. Although coregonids are strictly planktivorous and may achieve high biomasses in deep lakes, they seem to have only a limited capacity to induce pelagic trophic cascades down to phytoplankton. There are two reasons for their weak predation effects. First, coregonids have a relatively small gape size, and hence prefer small zooplankton prey such as Bosmina spp. (Schulz et al. 2003). In turn, they do not feed upon the large calanoid and cyclopoid copepods, which often dominate in the colder hypolimnetic layers of deep lakes. This strong size and species selectivity prevents that the total zooplankton density is massively affected by coregonid predation. Second, there is a spatial disconnect between coregonids and their preferred prey. While the coregonids prefer the colder hypolimnetic zones with temperatures around $10-12{ }^{\circ} \mathrm{C}$ and ascend into warmer water only during the night (Mehner et al. 2010), cladocerans grow best in the warm epilimnetic layers (Helland et al. 2007). Therefore, fish have only a limited time window during which they can feed upon their preferred prey. This short feeding period may explain why there is only a weak top-down effect of coregonids even on their preferred prey taxa.

Ultimately, we have to revise our expectation that zooplankton size distributions are sensitive to the feeding effect of fish and to environmental predictors. Although species- and size-selective feeding of coregonids is likely and has effects on the densities of the preferred taxa, these effects do not translate into a statistically significant modification of the entire SS. Instead, the SS seems to be relatively robust against predation effects, and seems to reflect the lake-wide energy availability and transfer efficiency in the food web (Mehner et al. 2018). This suggests that the classical pelagic food chain from fish to phytoplankton is only part of the lake food web. Creating SS across the majority of the organismal groups in both pelagic and benthic habitats might therefore allow inferring the major drivers of food web configurations. Furthermore, additional information on phytoplankton size distribution and taxonomy would allow a better mechanistic understanding of the interaction between phytoplankton and zooplankton communities. In our study, we used exclusively the chl a concentration as an indicator for phytoplankton biomass. However, many zooplankton species feed in a size- and speciesselective way. For example, juvenile daphniids usually avoid green filamentous algae, such as Ulothrix, whereas larger individuals include it in their diet (Chen et al. 2011). Shifts in phytoplankton composition and size structure, such as higher biomass of filamentous cyanobacteria induced by global warming (Selmeczy et al. 2019), may modify the strength of top-down effects of zooplankton on phytoplankton (Ersoy et al. 2017).

Our results are based on correlational evidence, which not necessarily allows implications of causal relationships. In particular, data on stomach content analyses or stable isotopes of fish would allow a better understanding of the strength of trophic links that ultimately affect the size distributions (Brose 2010; Boukal 2014). Furthermore, despite having included 
data from 13 successive years, in the framework of multiple linear regressions this is a low number of observations, and hence is associated with low statistical power (Hair et al. 2014). Accordingly, the overall surprisingly low number of significant multiple linear regressions here has to be considered cautiously. However, our study on pelagic trophic interactions and drivers of zooplankton SS may inspire others with significantly longer datasets to repeat a critical reconsideration of top-down and bottom-up effects on zooplankton size structure in stratified lakes.

Acknowledgements We would like to thank the technical staff of the department Experimental Limnology for taking, analysing and curating the long-term environmental and zooplankton data from Lake Stechlin. This study was financially supported by a grant from the German Research Foundation to TM and SB (DFG, Grant No. Me 1686/7-1). SB was partially financed by a grant from the Spanish Ministry of Science, Innovation and Universities (Grant No. RTI2018095363-B-I00).

Funding Open Access funding enabled and organized by Projekt DEAL.

Open Access This article is licensed under a Creative Commons Attribution 4.0 International License, which permits use, sharing, adaptation, distribution and reproduction in any medium or format, as long as you give appropriate credit to the original author(s) and the source, provide a link to the Creative Commons licence, and indicate if changes were made. The images or other third party material in this article are included in the article's Creative Commons licence, unless indicated otherwise in a credit line to the material. If material is not included in the article's Creative Commons licence and your intended use is not permitted by statutory regulation or exceeds the permitted use, you will need to obtain permission directly from the copyright holder. To view a copy of this licence, visit http://creativecommons.org/licenses/by/4.0/.

\section{References}

Ahrens MA, Peters RH (1991) Plankton community respiration: relationships with size distribution and lake trophy. Hydrobiologia 224:77-87

Akaike H (1974) A new look at the statistical model identification. IEEE Trans Autom Control 19:716-723. https:// doi.org/10.1109/TAC.1974.1100705

Andersen KH, Jacobsen NS, Farnsworth KD (2016) The theoretical foundations for size spectrum models of fish communities. Can J Fish Aquat Sci 73:575-588. https://doi.org/ 10.1139/cjfas-2015-0230

Atkinson D, Ciotti BJ, Montagnes DJS (2003) Protists decrease in size linearly with temperature: ca. $2.5 \%{ }^{\circ} \mathrm{C} 1$. Proc R Soc
Lond 270:2605-2611. https://doi.org/10.1098/rspb.2003. 2538

Auvinen H, Karjalainen J, Viljanen M (2000) Internationale Vereinigung für theoretische und angewandte Limnologie: Verhandlungen FLUCTUATION of year-class strength of vendace (Coregonus albula (L.)) in Lake Onkamo, eastern Finland. Verh Inrernat Verein Limnol 27:2057-2062. https://doi.org/10.1080/03680770.1998.11901601

Badosa A, Boix D, Brucet S et al (2007) Zooplankton taxonomic and size diversity in Mediterranean coastal lagoons (NE Iberian Peninsula): Influence of hydrology, nutrient composition, food resource availability and predation. Estuar Coast Shelf Sci 71:335-346. https://doi.org/10.1016/j.ecss. 2006.08.005

Balk H, Lindem T (2017) Sonar-4 and Sonar-5 post processing system. Oper Man version 604

Bartrons M, Mehner T, Argillier C et al (2020) Energy-based top-down and bottom-up relationships between fish community energy demand or production and phytoplankton across lakes at a continental scale. Limnol Oceanogr 65:892-902. https://doi.org/10.1002/lno.11434

Belsley D, Kuh E, Welsch R (1980) Regression diagnostics: identifying influential data and sources of collinearity. Wiley, New York

Bottrell HH, Duncan A, Gliwitcz Z (1976) A review of some problems in zooplankton production studies. Norw J Zool 24:419-456

Boukal DS (2014) Trait- and size-based descriptions of trophic links in freshwater food webs: current status and perspectives. J Limnol 73:171-185. https://doi.org/10.4081/ jlimnol.2014.826

Brooks JL, Dodson SI (1965) Predation, body size, and composition of plankton. Science (80- ) 150:28-35

Brose U (2010) Body-mass constraints on foraging behaviour determine population and food-web dynamics. Funct Ecol 24:28-34. https://doi.org/10.1111/j.1365-2435.2009. 01618.x

Brucet S, Boix D, López-Flores R et al (2006) Size and species diversity of zooplankton communities in fluctuating Mediterranean salt marshes. Estuar Coast Shelf Sci 67:424-432. https://doi.org/10.1016/j.ecss.2005.11.016

Brucet S, Boix D, Quintana XD et al (2010) Factors influencing zooplankton size structure at contrasting temperatures in coastal shallow lakes: implications for effects of climate change. Limnol Oceanogr 55:1697-1711. https://doi.org/ 10.4319/lo.2010.55.4.1697

Brucet S, Tavşanoğlu ÜN, Özen A et al (2017) Size-based interactions across trophic levels in food webs of shallow Mediterranean lakes. Freshw Biol 62:1819-1830. https:// doi.org/10.1111/fwb.12997

Calder W (1984) Size, function, and life history. Harvard University Press, Cambridge, MA

Carpenter SR, Cole JJ, Pace ML, Wilkinson GM (2016) Response of plankton to nutrients, planktivory and terrestrial organic matter: a model analysis of whole-lake experiments. Ecol Lett 19:230-239. https://doi.org/10. 1111/ele. 12558

Carpenter SR, Kitchell JF, Hodgson JR (1985) Cascading trophic interactions and lake productivity. Bioscience 35:634-639. https://doi.org/10.2307/1309989 
Chen F, Gulati RD, Li J, Liu Z (2011) A comparison of the size distribution of the filamentous green alga Ulothrix in Daphnia guts and lake water from Lake Taihu, China. J Plankton Res 33:1274-1283. https://doi.org/10.1093/ plankt/fbr029

Cottingham K (1999) Nutrients and zooplankton as multiple stressors of phytoplankton communities: evidence from size structure. Limnol Oceanogr 44:810-827

Cózar A, García CM, Gálvez JA (2003) Analysis of plankton size spectra irregularities in two subtropical shallow lakes (Esteros del Iberá, Argentina). Can J Fish Aquat Sci 60:411-420. https://doi.org/10.1139/f03-037

Edwards A (2020) Accounting for the bin structure of data removes bias when fitting size spectra. Mar Ecol Prog Ser 636:19-33

Edwards AM, Robinson JPW, Plank MJ et al (2017) Testing and recommending methods for fitting size spectra to data. Methods Ecol Evol 8:57-67. https://doi.org/10.1111/2041210X.12641

Einsle U (1993) Crustacea, copepoda, calanoida und cyclopoida. In: Schwoerbel J, Zwick P (eds) Die Süßwasserfauna von Mitteleuropa. Fischer, Stuttgart, pp 1-208

Elser JJ, Goldman CR (1991) Zooplankton effects on phytoplankton in lakes of contrasting trophic status. Limnol Oceanogr 36:64-90. https://doi.org/10.4319/lo.1991.36.1. 0064

Ersoy Z, Jeppesen E, Sgarzi S et al (2017) Size-based interactions and trophic transfer efficiency are modified by fish predation and cyanobacteria blooms in Lake Mývatn, Iceland. Freshw Biol 62:1942-1952. https://doi.org/10. 1111/fwb.13039

Flößner D (1972) Krebstiere, Crustacea: Kiemen und Blattfüßer, Branchiopoda, Fischläuse, Branchiura. In: Dahl F (ed) Die Tierwelt Deutschlands und der angrenzenden Meeresteile. Gustav Fischer, Jena, pp 1-501

Flößner D (2000) Die Haplopoda und Cladocera (ohne Bosminidae) Mitteleuropas. Backhuys, Leiden

Gaedke U, Seifried A, Adrian R (2004) Biomass size spectra and plankton diversity in a shallow eutrophic lake. Int Rev Hydrobiol 89:1-20. https://doi.org/10.1002/iroh. 200310661

Gardner JL, Peters A, Kearney MR, Heinsohn R (2011) Declining body size: A third universal response to warming? Individual-based modelling of animal movement under metabolic and microclimate constraints View project. Trends Ecol Evol 26:285-291. https://doi.org/10. 1016/j.tree.2011.03.005

Gjelland KØ, Bøhn T, Horne JK et al (2009) Planktivore vertical migration and shoaling under a subarctic light regime. Can J Fish Aquat Sci 66:525-539. https://doi.org/10.1139/F09014

Gulati RD, DeMott WR (1997) The role of food quality for zooplankton: remarks on the state -of-the-art, perspectives and priorities. Freshw Biol 38:753-768. https://doi.org/10. 1046/j.1365-2427.1997.00275.x

Hanson JM, Peters RH (1984) Empirical prediction of crustacean zooplankton biomass and profundal macrobenthos biomass in lakes. Can J Fish Aquat Sci 41:439-445. https:// doi.org/10.1139/f84-052

Hansson LA, Nicolle A, Brodersen J et al (2007) Consequences of fish predation, migration, and juvenile ontogeny on zooplankton spring dynamics. Limnol Oceanogr 52:696-706. https://doi.org/10.4319/lo.2007.52.2.0696

Havens KE, Pinto-Coelho RM, Beklioğlu M et al (2015) Temperature effects on body size of freshwater crustacean zooplankton from Greenland to the tropics. Hydrobiologia 743:27-35. https://doi.org/10.1007/s10750-014-2000-8

Helland IP, Freyhof J, Kasprzak P, Mehner T (2007) Temperature sensitivity of vertical distributions of zooplankton and planktivorous fish in a stratified lake. Oecologia 151:322-330. https://doi.org/10.1007/s00442-006-0541-x

Helminen H, Sarvala J (1994) Population regulation of vendace (Coregonus albula) in Lake Pyhäjärvi, southwest Finland. J Fish Biol 45:387-400. https://doi.org/10.1111/j.10958649.1994.tb01321.x

Jeppesen E, Jensen JP, Søndergaard M et al (1997) Top-down control in freshwater lakes: the role of nutrient state, submerged macrophytes and water depth. Hydrobiologia 342-343:151-164. https://doi.org/10.1007/978-94-0115648-6_17

Kasprzak P (1984) Bestimmung des Körperkohlenstoffes von Planktoncrustaceen. Limnologica 15:191-194

Kasprzak P, Schwabe W (1987) Some observations on the diurnal vertical migration of crustacean zooplankton in a stratified oligotrophic clear water lake (Lake Stechlin, GDR). Limnologica 18:297-311

Kerr S, Dickie L (2001) The biomass spectrum: a predator-prey theory of aquatic production. Columbia University Press

Kerr SR (1974) Theory of size distribution in ecological communities. J Fish Res Board Can 31:1859-1862. https://doi. org/10.1139/f74-241

Kiefer F, Fryer G (1978) Das Zooplankton der Binnengewässer (2. Teil). In: Elster H-J, Ohle W (eds) Die Binnengewässer, vol 26. Schweizerbart, Stuttgart, pp 1-380

Klein ZB, Quist MC, Dux AM, Corsi MP (2019) Size selectivity of sampling gears used to sample Kokanee. N Am J Fish Manag 39:343-352. https://doi.org/10.1002/nafm.10272

Koschel R, Adams D (2003) Lake Stechlin - an approach to understanding an oligotrophic lowland lake. Adv Limnol 58:1-311

Lieder US (1996) Crustacea, Cladocera, Bosminidae. In: Schwoerbel J, Zwick P (eds) Die Süßwasserfauna von Mitteleuropa. Fischer, Stuttgart, pp 1-80

Liu X, Beyrend D, Dur G, Ban S (2015) Combined effects of temperature and food concentration on growth and reproduction of Eodiaptomus japonicus (Copepoda: Calanoida) from Lake Biwa (Japan). Freshw Biol 60:2003-2018. https://doi.org/10.1111/fwb.12626

Liu X, Dur G, Ban S et al (2020) Planktivorous fish predation masks anthropogenic disturbances on decadal trends in zooplankton biomass and body size structure in Lake Biwa, Japan. Limnol Oceanogr 65:667-682. https://doi.org/10. 1002/lno.11336

Marquet P, Quiñones R, Biology SA et al (2005) U (2005) Scaling and power-laws in ecological systems. J Exp Biol 208:1749-1769. https://doi.org/10.1242/jeb.01588

McQueen JD, Post JR, Mills EL (1986) Trophic relationships in freshwater pelagic ecosystems. Can J Fish Aquat Sci 43:1571-1581. https://doi.org/10.1139/f86-195

Mehner T (2006a) Individual variability of diel vertical migrations in European vendace (Coregonus albula) explored by stationary vertical hydroacoustics. Ecol Freshw Fish 
15:146-153. https://doi.org/10.1111/j.1600-0633.2006. 00137.x

Mehner T (2006b) Prediction of hydroacoustic target strength of vendace (Coregonus albula) from concurrent trawl catches. Fish Res 79:162-169. https://doi.org/10.1016/j. fishres.2006.01.014

Mehner T, Busch S, Helland IP et al (2010) Temperature-related nocturnal vertical segregation of coexisting coregonids. Ecol Freshw Fish 19:408-419

Mehner T, Emmrich M, Kasprzak P (2011) Discrete thermal windows cause opposite response of sympatric cold-water fish species to annual temperature variability. Ecosphere 2:1-16. https://doi.org/10.1890/es11-00109.1

Mehner T, Lischke B, Scharnweber K et al (2018) Empirical correspondence between trophic transfer efficiency in freshwater food webs and the slope of their size spectra. Ecology 99:1463-1472. https://doi.org/10.1002/ecy.2347

Mehner T, Padisak J, Kasprzak P et al (2008) A test of food web hypotheses by exploring time series of fish, zooplankton and phytoplankton in an oligo-mesotrophic lake. Limnologica 38:179-188. https://doi.org/10.1016/j.limno.2008. 05.001

Mehner T, Schulz M (2002) Monthly variability of hydroacoustic fish stock estimates in a deep lake and its correlation to gillnet catches. J Fish Biol 61:1109-1121. https:// doi.org/10.1111/j.1095-8649.2002.tb02459.x

Mills EL, Schiavone A (1982) Evaluation of fish communities through assessment of zooplankton populations and measures of lake productivity. N Am J Fish Manag 2:14-27. https://doi.org/10.1577/1548-8659(1982)2\%3c14:eofcta\% 3e2.0.co; 2

Persson L, Diehl S (1992) Climate change induced regime shifts in Northern lake ecosystems View project Carbon dynamic in eutrophic lakes View project. https://doi.org/https://doi. org/10.1086/285403

Peters R (1983) The ecological implications of body size. Cambridge University Press, Cambridge

Pinto-Coelho R, Pinel-Alloul B, Méthot G, Havens KE (2005) Crustacean zooplankton in lakes and reservoirs of temperate and tropical regions: variation with trophic status. Can J Fish Aquat Sci 62:348-361. https://doi.org/10.1139/ F04-178

Quintana XD, Brucet S, Boix D et al (2008) A nonparametric method for the measurement of size diversity with emphasis on data standardization. Limnol Oceanogr Methods 6:75-86. https://doi.org/10.4319/lom.2008.6.75

Quintana XD, Egozcue JJ, Martínez-Abella O et al (2016) Update: A non-parametric method for the measurement of size diversity, with emphasis on data standardization. The measurement of the size evenness. Limnol Oceanogr Methods 14:408-413. https://doi.org/10.1002/lom3.10099

Rice J, Gislason H (1996) Patterns of change in the size spectra of numbers and diversity of the North Sea fish assemblage, as reflected in surveys and models. ICES J Mar Sci 53:1214-1225

Sarnelle O (1992) Nutrient enrichment and grazer effects on phytoplankton in lakes. Ecology 73:551-560

Scheuerell MD, Schindler DE (2003) Diel vertical migration by juvenile sockeye salmon: Empirical evidence for the antipredation window. Ecology 84:1713-1720. https://doi.
org/10.1890/0012-9658(2003)084[1713:DVMBJS]2.0.

$\mathrm{CO} ; 2$

Schulz M, Freyhof J (2003) Coregonus fontanae, a new springspawning cisco from Lake Stechlin, northern Germany (Salmoniformes: Coregonidae). Ichthyol Explor Freshw 14:209-216

Schulz M, Kasprzak P, Anwand K, T. Mehner T, (2003) Diet composition and food preference of vendace (Coregonus albula (L.)) in response to seasonal zooplankton succession in Lake Stechlin. Arch Hydrobiol Spec Issues Adv Limnol 58:215-226

Schulz M, Koschel R, Reese C, Mehner T (2004) Pelagic trophic transfer efficiency in an oligotrophic, dimictic deep lake (Lake Stechlin, Germany) and its relation to fisheries yield. Limnologica 34:264-273. https://doi.org/10.1016/S00759511(04)80050-1

Selmeczy GB, Abonyi A, Krienitz L et al (2019) Old sins have long shadows: climate change weakens efficiency of trophic coupling of phyto- and zooplankton in a deep oligomesotrophic lowland lake (Stechlin, Germany)-a causality analysis. Hydrobiologia 831:101-117. https:// doi.org/10.1007/s10750-018-3793-7

Sheldon RW, Prakash A, Sutcliffe WH (1972) The size distribution of particles in the ocean. Limnol Oceanogr 17:327-340. https://doi.org/10.4319/1o.1972.17.3.0327

Shurin JB, Clasen JL, Greig HS et al (2012) Warming shifts topdown and bottom-up control of pond food web structure and function. Philos Trans R Soc B Biol Sci 367:3008-3017. https://doi.org/10.1098/rstb.2012.0243

Sprules WG, Barth LE (2016) Surfing the biomass size spectrum: Some remarks on history, theory, and application. Can J Fish Aquat Sci 73:477-495. https://doi.org/10.1139/ cjfas-2015-0115

Sprules WG, Brandt SB, Stewart DJ (1991) Biomass size spectrum of the lake michigan pelagic food web article in canadian journal of fisheries and aquatic sciences. NRC Res Press 48:105-115. https://doi.org/10.1139/f91-015

Thiebaux ML, Dickie LM (1993) Structure of the body-size spectrum of the biomass in aquatic ecosystems: a consequence of allometry in predator-prey interactions. Can J Fish Aquat Sci 50:1308-1317. https://doi.org/10.1139/f93148

Tordesillas DT, Abaya P, Allyssa M et al (2016) Effect of temperature on life history traits of the invasive calanoid copepod Arctodiaptomus dorsalis (Marsh, 1907) from Lake Taal, Philippines. Plankt Benthos Res 11:105-111

Viljanen M, Väisänen P, Turunen T (2004) Fluctuations in yearclass strength and growth of the vendace (Coregonus albula (L.)) in the small, mesohumic, oligotrophic Suomunjärvi, a lake in eastern Finland. Ann Zool Fennici 41:241-248

Wanke T, Brämick U, Mehner T (2017) High stock density impairs growth, female condition and fecundity, but not quality of early reproductive stages in vendace (Coregonus albula). Fish Res 186:159-167. https://doi.org/10.1016/j. fishres.2016.08.028

Woodward G, Ebenman B, Emmerson M et al (2005) Body size in ecological networks. Trends Ecol Evol 20:402-409. https://doi.org/10.1016/j.tree.2005.04.005

Zhang J, Xie P, Tao M et al (2013) The impact of fish predation and cyanobacteria on zooplankton size structure in 96 
subtropical lakes. PLoS ONE 8:1-15. https://doi.org/10. 1371/journal.pone.0076378
Publisher's Note Springer Nature remains neutral with regard to jurisdictional claims in published maps and institutional affiliations. 